\title{
PHILOSOPHICAL PERSPECTIVES ON THE POLITICS AND CRISIS OF SUSTAINABLE DEVELOPMENT IN AFRICA
}

\author{
Ifechukwu J. Ndianefoo \\ doi: http://dx.doi.org/10.4314/og.v8i1.7
}

\section{Introduction}

At the dawn of independence from the colonial powers, the leaders of the new African states realized that political independence without economic power was phony. These leaders thus sought economic improvement of their states but their economic vision and resolve were soon respectively beclouded and weakened by internal power struggle amongst the political elites and the international conspiracy of the former colonial masters to keep these states in permanent economic dependency on the West.

Today, many decades after independence, the much vaunted vision and mission of the African states are far from being realized. New names have been given to old targets, problems and methods. In the current idiom of discourse, democratic consolidation has replaced post-independence grappling with rival socialist and capitalist ideologies of state craft. Sustainable development has encompassed and absorbed economic improvement. The old conspiracy of the former colonial masters and their allies to keep Africa in a state of permanent economic dependency on the West now assumes a form whereby the Breton Wood institutions design and impose development models on Africa.

This paper argues that the question of sustainable development has been politicized by internal power struggle amongst African political elites, on the one hand, and the international conspiracy of the former colonial masters and their allies, on the other. This paper further argues that such politicization has led to a crisis of sustainable development in Africa. It is posited that a veritable solution to the crisis of sustainable development in Africa lies in critical self-awareness leading to self-understanding on the part of the African peoples. It is further argued that philosophy is the proper handmaid for the recommended African critical self - awareness, 
self-understanding vis-a vis the global socio -economic and political environment.

This paper concludes that philosophy will enable the African achieve a critical and reconstructive engagement with his traditional, colonial, and contemporary heritage and in consequence liberate Africa from the thralldom of internal decadent and sadistic political elites and external Western conspiracy.

\section{Conceptualizing 'Philosophy' and 'Sustainable Development'}

The substance of this paper turns on its two predominant concepts, namely, "Philosophy" and "Sustainable development" It is important to delineate and fix the context of this paper by analyzing and explicating the ideas that have come to be associated with these terms.

Philosophy, like most of the disciplines in the humanities and the so-called social sciences, is susceptible to multifarious definitions or conceptualizations. This is because philosophy and these other disciplines deal with human nature and human nature is by itself complex and eludes definite and universal characterization. Philosophy as a theoretical discipline embraces a wide and diverse assortment of tendencies and approaches as the reflective, contemplative, speculative, analytical, critical, logical, activist, metaphysical (profound) and comprehensive. It is this wide and diverse concern that vests philosophy with the aura of a superscience that formulates and lays the general foundation for an ordered and systematic articulation of our thoughts and execution of our actions. It is in this light that philosophy occupies the preeminent position amongst disciplines and sits in judgment, so to speak, as an intellectual watch-dog, a patrol man, and a cultural legislator.

It is hoped that philosophy will acquit itself well in this over arching and advangardist role in attaining the now urgent need of sustainable development in Africa. Before we get to plumb that, let us acquaint ourselves with the ideas that ground the concept of sustainable development.

The concept of sustainable development is an advanced derivative of the root concept "development". So, as a matter of logical priority, we begin with explication of the fundamental 
concept, "development". As a social concept, development has been a source of hot ideological disputes over its meaning. Everyone defines it from his or her cultural and ideological matrix. Nonetheless, development can be classified into the physical, scientific, technological, moral, economic and social dimensions. But Bottomore takes a wholistic view of development and construes it to mean such factors as growth in political freedom and participation, growth of knowledge and growth of human control over the natural environment signaled by technological advancement and economic efficiency (Bottomore: 1962: 265) Iroegbu also has a wholistic view of development but with a progressive tinge. According to him:

Development is the progressive unfolding of the inner potentialities of a given reality. It is to de- envelop, that is, to bring out to light: the existential, functional and epistemic; what was enveloped, folded or hidden. As it applies to a people, development is the integration of the various givens: natural, physical, acquired and human of a people towards the full working out, permanently and cumulatively of their being as persons, of their community, and of their real productivity" (Iroegbu:1994: 81)

This paper employs development in this wholistic and progressive sense. The derivative concept of sustainable development is a culmination of capitalist and Neo-Marxist development theories of the late 1950 s and 1960 s. It is particularly traceable to a report put out by the Club of Rome in 1972, entitled 'Limits to Development'. This report made a case for sustainable development to contain the social dislocations and environmental problems that often result from economic development. The Brundtland Report (1987) viewed sustainable development as serving many different (and possibly competing) goals: economic development, a better environment and a particular concern for human wellbeing both now and in the further. (Atkinson,Dietz, and Neumayer: 2007: 1) Sustainable development concept found immediate favor with the United Nations and became a leading concept in their formulation of the development Endeavour in the Third World. It was conceived to check the steadily diminishing natural resources on the globe and at 
the same time meet the need to develop the poor countries of the World.

Nevertheless, like most of the development paradigms that have been formulated by the West and introduced in the Third World, sustainable development has a number of conceptual weaknesses and practical inadequacies. These conceptual and practical deficiencies have replicated themselves in the forms of politics and crisis of development in Africa to which we now turn seriatim.

\section{Politics of Development in Post -Colonial Africa}

Soon after attaining independence in the 1950s and 1960s, the new African leaders realized that political independence without economic power was phony. Hence, development became a national yearning in the new states of Africa. Much more significantly, the ideology of development came to replace for the new African leaders the old ideology of liberation.

Coupled to this continental yearning for development, the UN General Assembly in what appears to have been a wry sense of history, christened the 1960s the decade of independence and the 1970s and 1980s the First and Second Development Decades respectively for the Third World. As Otonti rightly observed, there seemed to be a happy coincidence between, on the one hand, the desire (real or imagined) of the First and Second Worlds to improve the lot of the Third World perhaps in partial atonement for the accumulated series of colonialism, and on the other hand, the determination of Third World Countries to escape from the thralldom of underdevelopment (Otonti: 2006: 4).

A pertinent question then is: why has Africa continued to reel under developmental crisis in spite of declared concern and presumed development programs of international agencies and efforts by African leaders? My answer to this question is that these local and international development programs were make believe. They were products of intense local and international politics by African leaders and governments of the countries of the First World respectively. As such these development programs were never meant to develop Africa, to raise the status of social existence of the African people to compare with the rest of the world. This State of affairs will be examined in some detail below. 
The politicization of development by African leaders will be considered first, beginning with the early post-independence period. African political environment at independence was profoundly hostile to development. The struggle for power was so intense and absorbing that everything else, including development, was peripheralised. The elites that were out of the power circle were constantly worried about their exposure to every kind of assault by a state that was hardly subject to any constitutional or institutional restraints. Since what mattered in this type of situation was the calculus of force, the out- of-power elites strove constantly to put together a credible force to challenge those in power or at any rate to limit their own vulnerability to harassment and abuse in a highly statist post- colonial polity.

Besieged by a multitude of hostile forces which their authoritarianism and exploitation practices had engendered, those in power were so involved in the struggle for survival that they could not address the problem of development nor could they abandon it. For sure, development was an attractive idea for forging solidarity and for uniting the fragmented political system. More importantly, it could not be abandoned because it was the ideology by which the political elite hoped to survive and reproduce its domination. Therefore, development got limited attention and served hardly any purpose as a frame work for economic transformation. Of course development plans were written and proclaimed. But what passed for development plans were aggregations of projects and objectives informed by the latest fads of the international community such as import substitution and export promotion.

Thus, the ideology of development itself became a problem for development because of the conflict between its apparent and real functions. The conflict is all too obvious in the actions of Africa leaders who proclaimed the need for development and made development the new ideology without necessarily translating it into a program of societal transformation. They did so not because they were uninterested in societal transformation but because their minds were absorbed in the struggle for power and survival.

How this crass trivialization and politicization of development which Ihonvere would call "hegermony of politics" (Ihonvbere: 1989:55) militates against real development in Africa is easy to see 
in the following examples of our socio-political experience. In the first place, there is a strong incompatibility between the pursuit of development on the one hand and the quest for political survival and the reproduction of political domination on the other hand. In so far as this incompatibility goes, our leaders quite naturally choose their political survival and the perpetuation of their domination over development. The damaging effects of this conflict are everywhere. It leads to the misuse of manpower resources and to inefficiency and corruption.

A related obstacle to development caused by African leader's politicization of development is the channeling of resources into unproductive uses. Here we see that important projects may be initiated for the wrong reasons, they may be located in places where they are least beneficial economically on account of political considerations. In Nigeria for instance, the huge financial resources sunk in transforming Kaduna into 'an artificial oil city' and the frenzied relocation of the Federal Capital to Abuja are outstanding misappropriation of developmental resources.

A further instance of how politics under develops Africa is seen in the economic implications of authoritarianism and militarization of politics. Authoritarianism and militarization of politics and, by extension, the societies are the outcome of overvaluing of political power in Africa and the intense struggle to obtain and keep it. This has transformed politics in Africa into warfare. It is against this backdrop that we would appreciate the poignancy of the worries and conclusion of Claude Ake, a fore most Marxist intellectual and political economist that:

Three decades of preoccupation with development in Africa have yielded meager returns. African economies have been stagnating or regressing. For most Africans, real incomes are lower than they were two decades ago, health prospects are poorer, malnourishment is widespread and infrastructure is breaking down as are some social institutions. Many factors have been offered to explain the apparent failure of the development enterprise in Africa: the colonial legacy, social pluralism and its centrifugal 
tendencies, the corruption of leaders, lack of entrepreneurial skills etc... The problem is not so much that development has failed as that it was never really on the agenda in the first place. By all indications political conditions in Africa are the greatest impediment to development..... African politics has been constituted to prevent the pursuit of development and the emergence of relevant and effective development paradigm and programs (Ake: 1996:1).

Although Prof. Ake's observations and conclusion were made more than a decade ago, the political conditions in Africa have remained the same in some cases and worsened in others. In Nigeria for example, vicious politics brought the military into governance and has made the country to lurch from one military dictatorship to another for nearly two decades. After the military relinquished power in 1999, Nigeria's civilian president, Obasanjo declared the 2007 elections as "a do-or-die election" and commissioned some violent and reprobate politicians like Chief Lamidi Adedibu as his "garrison commander" of garrison politics. A foremost columnist of a foremost newspaper in Nigeria, Tatalo Alamu, wrote about Nigerian politics thus:

In Nigeria, politics has become the continuation of war by other means. Politics is civil war fought with major artillery ... the militarization of Nigeria's political culture and the socialization of our people to the habits of war in politics has become endemic. Now bombs have arrived at rallies, political assassinations have become the norm... (The Nation, vol. 5, no 1689 March 6, 2011: 3).

It is less than five years Liberia and Sudan emerged from long civil war precipitated by vicious politics of their political elites. The power struggle between Thabo Mbeki and Jacob Zuma (within the ruling ANC party) in South Africa forestalls further development and even pares off the little development achieved under the white minority regime. 
Zimbabwe and Kenya are still in the throes of post-election crisis for there to be attention to any development planning and execution as a result of the power tussle between Mugabe and Tchangarai and Kibaki and Odinga respectively. Ivory Coast's relative political and economic stability went with the death of President Houphet Boigny. Vicious politics has turned the country into a vortex of civil tension and civil war by virtue of the power tussle between Laurent Gbagbo and Alsaine Qattara.

Instances of how vicious politics under develops Africa are too many to bear recounting here. Suffice it to say that these internal political conditions in Africa are further compounded by the external Western political manipulations of development enterprise in Africa. To this, we now turn.

In introducing the external aspect of the phenomenon of how politics under develops Africa, I qualified that external political force as "Western" by which I mean Western Europe and America. This qualification is for the following reason. Although much of the ideological warfare (cold war) which reached its climax in the 1960s was fought over development, that is, whether the so-called "free world model (capitalism) or the Communist Model (communism)" would be adopted by the developing nations (Daniel Offiong: 1980:12), it was the West that had the upper hand. This is because the west colonized Africa and had entrenched her culture in Africa. Consequently, the West commanded and still commands dominant control over these independent states. What is more, the institutions like World Bank, IMF, GATT etc which formulate and dictate world-dominant economic and developmental models and policies are Western.

These international organizations are agents of Western imperialism and are in Africa to sell the world view of their principals and deepen the latter's influence and power over the former economically, politically and culturally. This is why the underdevelopment of Africa by African leaders' obsession with vicious politics of survival in power cannot be fully understood outside the overarching influence of Western imperialism. In fact they reinforce each other. The African leaders' obsession with politics rendered them unable to invent and pursue genuine development strategy to make African states economically and 
militarily strong. In the end and in frustration, African leaders turned to the West for both economic aids and economic development models. The former colonial masters exploited and celebrated this circumstance. They handed out paltry economic aids and grants and tendentious economic theories and doctrines to further their imperialism which ensured that the new independent states became permanent producers of raw materials that were also strategically and conspiratorially low-priced in the international market, while these former colonial masters became permanent producers of overpriced finished goods, machines, and expertise. In this-way, Africa's economic dependency on the west became effectively established as an instance of a dubious international division of labor. To disguise their imperialist agenda, the multinational corporations, United Nations agencies, the World Bank and IMF approach economic development without much regard for its political context. Thus, they cultivated the myth that development projects and development strategies are politically unproblematic and that brining political considerations to bear on them is an undesirable complication. They encourage the view that the problems of underdevelopment are quite clear and that the measures required for dealing with them are obvious.

As vanguards of Western imperialism and capitalism, these international organizations cannot bring themselves to deal with real development of Africa. When they insist on a favorable investment climate they have in mind certain political conditions, namely: the willingness of the political class to cooperate with their imperialist design and profit-marking projects, and also a commitment on the part of the political class to rule with a strong hand and to keep labor and its demands under control and to shun welfarist measures.

In the light of all this, we see that both African leaders and the West who speak of African development and make development policies are the people least suited for the role. The broad sections of African people whose wellbeing constitute the whole point of development have no say in development. The interests that inform prevailing development strategies are invariably in conflict with popular interest. Thus, the developmental relevance of these strategies is questionable. There is indeed no relationship between public policies and social needs. The populace is merely the means 
to the ends of narrow interests. They are not, as they should be, the end and the inspiration of the development process. Although coercion ensures the people's conformity, it also ironically induces the withdrawal of their commitment and the de-mobilization of their energy without which there can be no development.

As long as these political conditions persist, Africa will continue to flounder in her development efforts. Unfortunately, these political conditions persist and have plunged African into developmental crisis. This developmental crisis is the subject of the next section of this paper to which we now turn.

\section{Features of the Crisis of Development in Africa}

Hitherto it has been argued that, the politics of neo-colonialism and the African leaders' obsession with struggle for political domination have, more than any other factors, made Africa to continue to squirm in the nether regions of the underdeveloped world. These two catalysts of African underdevelopment are in some strange and fatal dialectical relationship. These reinforce each other in the sense that the struggle for political domination and survival made it impracticable for the African to embark on development-oriented governance and thus had to fall back on the former colonial masters for development assistance. This is on one hand. On the other hand, the West disencourage and disorganize development of Africa which they rightly fear would terminate the economic dependence of Africa on the West. The West therefore employ broad-based neo-colonial infrastructure (which include aids, grants, debt peonage, the Breton woods institutions and discrete political influence) to impose unrealistic and unworkable development strategies and paradigms on Africa

In the remaining part of this section we will examine the character or features of African developmental crisis. A fundamental feature is the conflict in developmental agendas. The African rulers' unwarranted recourse to the former colonial masters for development assistance produced a conflict over development agendas between Africa's rulers and the international development agencies which are, by their conception and composition, the handmaid of western imperialism and neo-colonialism. The conflict ensued because the western development agenda for Africa was 
severely limited by their political interests which were often in conflict with the prerequisites of real development. The western development paradigm conceives development as an autonomous process, independent of politics, culture and institutional framework. According to Claude Ake, this conception of development offered for the foreign patrons of Africa the advantage of dehistoricizing development, so that it was easier to represent their values and experience as objectively desirable and inevitable (Ake:1996:12).

Western development paradigm was thus projected as universal model of development. In consequence, there came to be a mounting anarchy of development studies and development practices in Africa which are more or less the bits and pieces borrowed from theories and paradigms constructed after western historicity and specificities.

Nowhere is the conflict more evident than in the rift between the Breton Woods's institutions and African governments over approaches to African development. The high points of the conflict include the Breton Woods's institutions' formulation and advocacy of the policy of Accelerated Development for Africa, their veiled opposition to Lagos Plan of Action and the much maligned Structural Adjustment Program.

We start with the Accelerated Development for Africa. The Accelerated Development was a Socio-economic development policy authored by the World Bank and IMF upon the request of African leaders in the latter's reaction to the World Bank Report of 1972 which presented a bleak future of Africa's development prospects. The Accelerated Development Report recommended that Africa should concentrate on primary production, particularly agricultural products. By emphasizing agricultural production for export, the Accelerated Development Report was reinforcing Africa's dependence on hostile international market that the West has strategically made protectionist to their favor.

Further rift over approaches to African development is seen in Breton woods institutions' veiled opposition to the Lagos Plan of Action because they know it was well-thought out and cogent and would terminate Africa's economic dependence on the West. The Lagos Plan of Action was adopted as a blue-print for the economic and political emancipation of Africa by the Assembly of Heads of States and Governments of the OAU at its Second Extraordinary 
Meeting devoted to economic development problems in April, 1980. The Plan, to a large extent, demonstrates the fact that Africa's leaders were coming to grips with the realities of the deepening crisis facing their economies. The Plan, therefore, enabled the leaders revaluate their inheritance, location, and role in the World system and to map out new paths to self-reliant growth and development.

The Breton Woods institutions' veiled opposition to the Lagos plan of Action was expressed by their ignoring it and refusing to reorient their economic relations with Africa so as to ensure the realization of the Plan. That opposition was enough to render the Plan in operable. In the end, African leaders found that they were too dependent and too weak to have their way and they started to retreat. They talked less about the Lagos Plan of Action and signaled their willingness to reform their economies along the line suggested by the Work Bank study, and most significantly, they increasingly adopted structural adjustment programs of the World Bank and IMF which also had conflictual impact on African economies.

The structural adjustment is an economic and financial model developed by Jacques J. Polak in 1957. It became controversial because of the unsuitability of its theoretical assumptions to African conditions and this explains why its application in Africa worsened African economics in the 80s. Apart from the privatization, devaluation and deregulation aspects of the structural adjustment program, its governing doctrine of free reign of market forces has continued to perpetuate Africa's location in the international division of labour in which she is relegated to the role of primary producers and mere consumers of manufactured.

Besides the above conflict in developmental agendas, the predatory economic relations between Africa and the west have also produced the following features of African developmental crisis, namely dependence, disarticulation and narrow resource base. The combined effect of these malignant features of the African economy has a strong tie with the metropolitan Western economy so much so that they may be said to be an integral part of the metropolitan economy. It is precisely because of these vertical ties between sectors of the periphery economy to the centre that African economies have become so disarticulated, dependent and narrow 
resource based. It is against this backdrop that Ake made the conclusion that "to the extent that an economy is disarticulated its capacity for independence is diminished, and to the extent that an economy is dependent it is more prone to disarticulation" (Ake: 1981:136).

A further and, of course, the last feature of the crisis of African development that will be considered in this paper is the ambivalent approach of African leaders towards development which Ake pejoratively described as ideology of development (Ake:1981:139). African rulers and technocrats are aware that dependence, disarticulation and the narrow resource base of their economies underlie the underdevelopment which threatens the credibility of their leadership. Hence they are clearly anxious to do something about it but the realization of the requisite change is limited by fear of confrontation with Western Capital on which the African rulers and technocrats depend so heavily for their prosperity and security. African rulers and technocrats have tried to deal with this dilemma by making an ideology of development. By their incessant elaboration of this ideology they are able to convey to their people the impression of immense concern with their poverty and the economic backwardness of their country as well as their determination to tackle the problem of getting out of this backwardness with the utmost sense of urgency. This wins them some legitimacy at a price of abandoning real development in the context of African historicity and specificities. Their notion of emerging out of economic backwardness amounts essentially to westernization and industrialization. They hypocritically pursue development within the existing neo-colonial socio-economic structure. So it was relatively easy for the African rulers to avoid some kind of confrontation with Western Capital.

Despite appearances to the contrary, the ambivalent and duplicitous ideology of development of African rulers and technocrats has remained an entrenched practice aided by agents of Western Capital. The latest and supposedly the best collective African response to the continent's development crisis is the New Partnership for African Development (NEPAD) adopted at the $37^{\text {th }}$ Session of the Assembly of Heads of States and Government of the African Union in July 2001 to "eradicate poverty, promote 
sustainable growth and development, integrate Africa in the World economy, and accelerate the empowerment of women" (Okpeh: 2005:15).

Unfortunately, the neo-liberal philosophy and ideology of development which African rulers and technocrats have accepted as legitimate universal worldviews has tragically predisposed the authors of NEPD to take-off on wrong assumptions. Hence NEPAD is flawed analysis and interpretation of the African crisis of development; it does not reflect the concrete realities of the African situation.

Also as a result of the conspiracy between African ruling elites and their western patrons on the duplicitous ideology of development, the G8 has mounted the Millennium Development Goals which is a charade of development, the West's complement to duplicitous ideology of development. The MDGS funds are mere palliatives released from the Western storehouses impelled by the dictates of their pricked conscience over their structural underdevelopment of African since $15^{\text {th }}$ century. If the MDGS are not mere palliatives, why does the West through the instrumentality of the World Bank, IMF, GATT and their satellite agencies continue to maintain unfair international trade regimes that are strategically and conspiratorially skewed to make African permanent producers of raw materials and consumers of finished goods and services? Why has the West through the World Bank and the IMF continued to seek the devaluation of African currencies such that as recent as March, 2011,the IMF Representative in Nigeria, Mr. W. S. Rogers claimed that, Naira, the Nigerian currency, was over valued and called on the Nigerian Central Bank to devalue the Naira (The Nation March20:2011:57).

Today, the din and excitement over NEPAD and MDGS have become muted with the realization of their impotence as development agendas. Africa remains trapped in the circle of underdevelopment. Africa needs to reinvent her destiny. Africa needs to harness her immense raw material deposits and large population to resuscitate her economies and attain quality life for her peoples. To achieve this, Africa needs philosophical re-thinking and re-appraisal of her socio-economic and political development assumptions, methodologies and goals as well as the entire 
principles of her engagement with the West. Such philosophical rethinking and re-appraisal would naturally lead to the creation of an ideology and philosophy of African development. Such philosophical interrogation and re-discovery is the focus of the next segment of this paper.

\section{Philosophical Perspectives}

The predominant task of this paper is to proffer philosophical solution to the problem of sustainable development in Africa, the causes of which have been identified above as the obsession with the acquisition of political power and its perpetuation on the part of African leaders, on the one hand, and western imperialism and neocolonialism, on the other. That such a philosophical solution is primary amongst others and indeed drives them is too obvious to argue. Philosophy by its nature is a presuppositionless, logical, critical, analytical and systematic discipline with a comprehensive and integrativist breadth. It is this mega-character which makes philosophy a mega-discipline and a cultural legislator. As a cultural legislator, philosophy interrogates the entire culture of a people-their arts, values, customs, laws and science - by subjecting the assumptions, theories and goals to critical analysis and re-appraisal and pointing the way toward enlightened existence and general development of the people.

It is in recognition of this fundamental role of philosophy that United Nations Educational Scientific and Cultural Organization (UNESCO) in 2002 in its Paris Headquarters inaugurated the World Philosophy Day to be celebrated as an annual event of global import. Among other goals, the celebration is aimed at: Bringing philosophic education to all peoples of the world; Reliving the perennial relevance of philosophy to mankind's search for global peace, justice and development; and Inspiring more people to live the examined life of philosophical reflection.

Africa, in the face of her enormous development challenges, needs philosophy and it is indisputable that philosophy can do for Africa what it has done for the West in their hours of need, in their pre-industrial era. Africa cannot rightly claim that she is in her industrial era. Although Africans use and enjoy industrial products, these are not produced by Africans in Africa. I have had to 
repeatedly ask my students to take inventory of "contemporary goods" in their immediate environment and note how many of such goods are made in Nigeria. Based on their chattering realization, I always added salt to their injuries by telling them we are in false modernity. By extension, Africa is in a false industrial era. Africa is in industrial era vicariously. Going by the theory of development which this paper advocates and which conceives development as harnessing of a people's natural resources to ensure the quality and quantity of their life, Africa has not been able to convert significantly her abundant natural resources into life-supporting and life-imparting industrial goods. Unless Africa is able to do this, Africa cannot boast of development but instead may lament underdevelopment and the consequent regression.

African leaders and technocrats must therefor evolve a philosophy and ideology of development based on Africa's peculiar cultures, colonial experiences and contemporary realities. Such endogenous, context-bound ideologies and philosophies were evolved and employed by the Asia-Pasific countries like China, Japan and the proverbial Asian Tigers. Particularly outstanding examples in this regard are China and Japan whose religious, political and economic ideologies and philosophies are in- extricably woven together and, in combination with modern science, have placed them in the enviable position of leading world economies.

To be able to evolve such an ideology and philosophy of development which this essay seeks to contribute to, Africans must take advantage of the philosophical insight that political power is contractual and as such should be employed only towards securing a just and viable society. Such philosophical insight would reverse the current obsession with political power and it's perpetuation by all means. Africa must also subject western theories and doctrines of development and governance to rigorous philosophical evaluation to appropriate what is useful and jettison what is not. Such philosophical evaluation will necessitate what a leading African philosopher, Kwasi Wiredu, has termed "conceptual decolonization" that is, a critical self-awareness against unexamined assimilation of western categories or concepts and theories (Kwasi Wiredu: 1995:22). To be able to carry out the required philosophical evaluation or critique of western concepts, theories and doctrines 
that will lead to the envisaged cultural decolonization and unleash the African genius, Africa must experience a gnoseological or epistemological breakthrough.

By achieving gnoseological or epistemological breakthrough, one does not mean knowledge in its rucksack sense (as Dearden calls it) which equates knowledge with useful bits of information, the acquisition of which can, for instance help one obtain employment, preferably in an office, and acquire wealth and all that goes with it (Dearden:1986:61). Instead, we mean philosophical knowledge which emphasizes the understanding of principles, the questioning of accepted facts and dogmas, the acquisition of information-getting skills, in short, the development of inquiring mind. Such philosophical knowledge will impart rationality to the African which will enable him to raise fundamental questions about African experience, about himself, his culture, religion, etc and thereby gain deeper self-knowledge, the knowledge of the African world and the entire global reality in a most profound, comprehensive and coherent manner.

To achieve the gnoseological or epistemological breakthrough, Africa has no choice but to mount a mass education policy refocused on acquiring the philosophic temper of mind which the UNESCO World Philosophy Day inauguration seeks to inculcate in peoples of the World. Acquiring such a philosophic temper will help Africans ask and solve such basic questions as: What type of society they want to build? Is it a semi-religious oligarchy or a secular-state, tradition-bound or scientifically-oriented, capitalist or socialist, just or unjust, elitist or egalitarian? Does the present configuration of the United Nations promote mutual respect of Nations and peoples of the world? Do the present international economic relations which make Africa permanent producers of cheap raw materials represent a cosmic order of things?; and so on. It is to be quickly noted that such attainment of philosophic temper of mind naturally leads to scientific renaissance as witnessed in ancient Greece and the $15^{\text {th }}$ and $16^{\text {th }}$ centuries after philosophy helped to unleash science from the grip of religion.

Apart from government's conscious re-focusing of mass education along the philosophic lines recommended by UNESCO, there is yet a very potent means towards achieving that. The civil 
society groups otherwise known as NGOs can go a long way in training citizens to imbibe the philosophical habits of critical selfawareness and critical engagement with one's society through strengthened drive and broadened perspectives. It is a happy development that the NGOs are beginning to be specialized as they now segment into human rights, environmental, good governance, women and youth empowerment groups. But it is lamentable that African governments which allocate huge financial resources in the budget to fund political parties loathe giving a dime to the NGOS nor do the banks and companies which secretly contribute to political campaign funds. The international organizations that occasionally donate money to African NGOS do not go beyond mere symbolic gestures in terms of the paltry sums handed out. All this is understandable against the historical background that the Establishment has ever been wary and suspicious of philosophy because of what Professor A. Baikie described as its "heady abstractions and iconoclastic nature" (Otonti: 2006:132). Did the Athenian parliament not condemn the social gadfly Socrates to death with hemlock? Did emperor Justinian not banish philosophers from Rome? Rousseau and Marx were chased from one country's border to the other because of their radical philosophies. Martin Luther Jr. and Malcolm X paid dearly for championing the philosophy and ideology of equal rights for blacks in America. The list is endless. But the impact of philosophical enlightenment has been decisive and revolutionary.

The triumph of philosophical enlightenment over the oppressive forces of conservatism and regressive traditions has remained a hope and its justification amongst peoples. Africa needs philosophical enlightenment to achieve gnoseological or epistemological breakthrough to unleash the potential genius of her peoples. A great lesson for Africa is contained in the words of Prof. Nduka Otonti:

That the Western world is now being run on more rational, indeed scientific, principles than most of the underdeveloped world is one of the consequences of the adoption of a more rational attitude towards human life and society. (2006:136).

S.H. Alatas follows the line of thought of Otonti and definitively states that "the cause of prevailing backwardness of the developing 
societies is that there was no intellectual and philosophical revolution preceding the modernization and development process" (Alatas: 1977:79). Alatas observation is made upon the realization that the so-called "development and modernization "process" are not the products of our thoughts as they ought to be; they are not, to use the words of Hegelian idealism, the objectification or externalization of African mental infrastructure. Alatas indeed corroborates the earlier argument of this paper that Africa can not be said to be in the industrial era because we did not contribute significantly to the resulting industrial goods. Our own industrialism is arrested by the non-existence of the philosophy and ideology that drives a people, such as drove the British, Germans, Americans, Russians, the French, the Chinese, and the Japanese et al to the enviable class of developed nations.

The literacy level in Africa can support a mass campaign for the evolution of such philosophy and ideology using the governmental and civil society options discussed above. Africa is already too far in arrears regarding the need to inaugurate such a philosophy. Over fifty years ago, at the maiden conference of independent African states, the late African patriot, Kwame Nkrumah, reminded Africans that just as Europeans discovered Africa, it is expected that African philosophers will be of immense help to the rediscovery and development of Africa. This paper is an unflinching response to Nkrumah's hopes that philosophy as an engine of human and social development would lead Africa to rediscover and harness her natural potentials. Such rediscovery and harnessing of our natural potentials, as I have argued in the preceding paragraphs, is a function of gnoseological or epistemological break through.

It remains to add that the gnoseological break-through which philosophy drives should be brought to bear on the false consciousness about African and global realities created in the African by western imperialism and neocolonialism. Africans must in the light of the knowledge break-through critique the assumptions and goals of such bearers of false consciousness as the following neo-colonial concepts, theories and agencies- the World Bank, IMF, GATT, Structural Adjustment, Program, Millennium Development Goals, capacity building, development and growth paradigms and so on. The ostensible meanings and functions which the West put on 
these concepts, theories and agencies are quite different from their actual meanings and functions in the global socio-economic and political dynamics. This is why Africans should ensure and maintain a position of theoretical and practical vigilance to unmask these misleading theories and agencies as they come. Having done that, Africans should engage their native resources and evolve homegrown responses and options to development driven by an autochthonous philosophy and ideology of development suitable to individual peoples of Africa.

\section{Conclusion}

Analysts have attempted to diagnose the root causes of the African crisis which is, in the last analysis, a crisis of agendas on how to transform Africa from her present ridiculous status of being the granary of Western and Asia pacific capitalist production. This paper takes the distinctive position that Africa's developmental crisis is essentially a problem of the mind and equally requires a mind solution. Africa requires a gnoseological break-through to evolve a philosophical and intellectual revolution to: see through the thicket of western duplicity and neo-colonialism camouflaged as development theories, interventions and partnership and to reject these as false options that they are. It is African mind that will develop African continent. Thinking or hoping that any form of partnership with the West can achieve development for Africa is not only in authentic butt delusive. The West is not Africa's friends. They were once our harsh masters. When they left, they left with a grumble. Today the West operate as subtle masters over Africa culturally, economically and politically through the instrumentality of the so-called development theories, interventions and partnerships.

The woeful failure of the much vaunted transfer of technology of the 1980s should be a lesson to Africa to urgently inaugurate her own philosophical and intellectual revolution (as the west once did) and lift herself by her own bootstraps to go beyond primary or agricultural production into secondary production or manufacturing. 


\section{References}

Ake, Claude, Democracy and Development in Africa. Ibadan: Spectrum Books, 1996.

A political Economy of Africa. Ibadan: Longman, 1981.

Alatas, S.H, Intellectuals in Developing Countries. London: Frank, 1977.

Atkinson Giles, Dietz Simon, and Noumayer Eric.eds. A HandBook of Sustainable Development Massachusetts: Edward Elgar Publishers lnc. 2007.

Bottomore, T.B,Sociology: A Guide to Problems and Literature London: Allen and Unwin, 1962.

Dearden, R.F, The Philosophy of Primary Education. London: Routledge and Kegan Paul, 1968.

Federici Silvia, Caffentzis George and Allidou Ousseina,eds. A Thousand Flowers: Social Struggles Against Structural Adjustment in African Universities. Asinara: Africa World Press Inc. 2000.

Ihonvbere, J. ed. The Political Economy of Crisis and Underdevelopment in Africa. Lagos: JAD Publishers, 1989.

Iroegbu, P. Enwisdomization and African Philosophy. Owerri: International Universities Press Ltd. 1994.

Odimeqwu, I. Philosophy and Africa. Amawbia: Lumos Nigeria Ltd. 2006.

Offiong, D. Imperialism and Dependency: Obstacles to African Development. Enugu: Fourth Dimension Publishers. 1980.

Otonti, N. The Roots of African Underdevelopment. Ibadan: Spectrum Books, 2006.

Okpe, O.O, NEPAD and the African Crisis. Makurdi: Aboki Publishers, 2005.

Wiredu, K. Conceptual Decolonization in African Philosophy Ibadan: Hope Publications, 1995. 